\title{
Comparative Histological Study on the Effect of Allium Sativum (Garlic), Allium Cepa (Onion) and Insulin on Lingual Papillae of Diabetic Rats
} Original Article

\author{
Rania Ahmed Awwad ${ }^{1}$ and Reham Ahmed Abd Rabbo ${ }^{2}$
}

Oral Biology Department, Faculty of Dentistry, Ain Shams University, Cairo, Egypt

\begin{abstract}
Introduction: Diabetes mellitus (DM) is a common chronic metabolic disease. Various inflammatory diseases and soft tissue pathologies are associated with DM. Major concern in diabetes is oxidative stress. Antioxidants prevent diabetic complications. Onion \& garlic are strong antioxidants, so this study was done to determine their possible effect in minimizing complications that diabetic patients suffer, compared to insulin.

Materials and Methods: Fifty Albino rats were divided into 5 groups, ten rats each; Control, untreated streptozotocin induced diabetic group, diabetic insulin treated, diabetic garlic treated and diabetic onion treated groups. On the $21^{\text {st }}$ day of the experiment, rats were sacrificed and tongue specimens were prepared and examined by H\&E for routine histological examination and by scanning Electron Microscope.

Results: Histological changes of tongue papillae of diabetic untreated rats were observed, such as thinning of the epithelium of all papillae, numerous intra-epithelial cell vacuolations, thin detached keratin, extrcellular edema and inflammatory cell infiltrate within the lamina properia of all papillae. After, administration of insulin, garlic and onion, tongue papillae appeared almost normal compared to control group. However, the onion group displayed apparently slight better morphological and structural findings than garlic group.

Discussion: Circumvallate papillae were most affected may be due to difference in their gustatory nerve supply. Other papillae in both garlic and onion treated groups, appeared almost normal. Which can be explained by the hypoglycemic, antimicrobial, anti-inflammatory effect of both extracts.

Conclusion: Garlic and onion oral intake during early phases of diabetes caused valuable improvement of tongue papillae which was highly comparable to insulin treatment.
\end{abstract}

Received: 30 March 2020, Accepted: 23 June 2020

Key Words: Antioxidants, diabetes mellitus, tongue papilla.

Corresponding Author: Rania Ahmed Awwad, PhD, Oral Biology Department, Faculty of Dentistry, Ain Shams University, Cairo, Egypt, Tel.: +20 1222390329, E-mail: rania.a.awwad@dent.asu.edu.eg

ISSN: $1110-0559$, Vol. 43, No.2

\section{INTRODUCTION}

Diabetes mellitus (DM) is a growing public health concern and a common chronic metabolic disease worldwide ${ }^{[1]}$. DM represents a group of metabolic diseases that are characterized by hyperglycemia due to a total or relative lack of insulin secretion and insulin resistance or both. The World Health Organization (WHO) has recently declared it to be a pandemic ${ }^{[2]}$. Unfortunately, Diabetes has been shown to be a state of increased free radical production $^{[3]}$. Moreover, various inflammatory diseases and soft tissue pathologies in oral cavities are associated with DM. The major concern in DM is increased oxidative stress. Therefore, dietary supplementation with antioxidants such as vitamins, and flavonoids has been used in attempts to prevent the occurrence of many diabetes complications. There is a protective biochemical function of natural antioxidants contained in dietary plants, which make them candidates for prevention or protection of oxidative damage caused by free radical species ${ }^{[4]}$. Since onion and garlic are strong antioxidants and free radical scavengers and diabetes on the other hand, produce oxygen free radicals, so this study is carried out to determine their possible effect in minimizing DM complications, such as vasculopathies, neuropathies, ophthalmopathies and nephropathies, that diabetic patients could suffer, in comparison with insulin.

\section{AIM OF THE STUDY}

To assess the possible effect of onion \& garlic in comparison with insulin; in reducing the complications that diabetic patients may suffer through examination of lingual papillae of diabetic Albino rats by routine light microscope and scanning electron microscope examination.

\section{MATERIALS AND METHODS}

\section{Animals}

Fifty male Wistar Albino rats of average weight 200-250 gms were used in this study. The rats were housed in separate cages, five rats per cage, in the Animal House of the "Medical Research Center" in Ain Shams University throughout the duration of the experiment. This was done under supervision 
of specialized veterinarian since their housing till getting rid of terminated bodies which was done in the Incinerator of Ain Shams University Hospital.

Rats were kept under good ventilation and adequate diet of standard rat chow, and tap water throughout the experimental period. The Bio-ethical Research Committee of the Faculty of Dentistry, Ain Shams University reviewed the proposal and all the steps of experiment were done according to the roles approved by them.

\section{Materials}

1. Streptozotocin (STZ): It was purchased from Sigma company and obtained in powder form. It was dissolved in freshly prepared citrate buffer before use.

2. Insulin: Novonordisc mixtard 30, $100 \mathrm{U} \backslash \mathrm{ml}$. It was purchased from a local pharmacy.

3. Garlic (Allium Sativum): It was purchased from the hypermarket in the form of pure dried powder with no other additives. It was produced by (Aldoha company, Egypt). Garlic powder was given with a dose $150 \mathrm{mg} / \mathrm{kg}$ per day ${ }^{[5]}$.

4. Onion (Allium Cepa): It was purchased from the hypermarket in the form of pure dried onion powder with no other additives. It was produced by (Aldoha company, Egypt). Onion powder was given with a dose 1.5 gm $\mid$ rat $\backslash$ day ${ }^{[6]}$.

\section{Induction of D.M}

The blood glucose levels for each group of rats were measured before the start of the experiment and after the induction of Diabetes.

Diabetes was induced by injection of a single intraperitoneal dose of STZ $(50 \mathrm{mg} / \mathrm{kg})$ in citrate buffer ${ }^{[7]}$.

Because of the unstable nature of STZ, it was freshly dissolved in $1 \mathrm{ml}$ of $0.05 \mathrm{M}$ citrate buffer ( $\mathrm{PH} 4.5$ ) 10 minutes prior to injections into the rats.

The citrate buffer was prepared at the pharmacognosy department of The National Research Centre by adding $47 \mathrm{ml}$ of 0.05 molar citric acid to $53 \mathrm{ml}$ of 0.05 molar trisodium citrate dihydrate ${ }^{[8]}$.

\section{Experimental Design}

The fifty Albino rats were randomly divided into 5 groups, ten rats each.

\section{Control Group (CG):}

10 Rats were injected with citrate buffer intraperitoneal (IP) for one time at the beginning of the study.

\section{Diabetic Groups:}

40 Rats will be injected with STZ $(50 \mathrm{mg} / \mathrm{kg}$ of body weight) IP for one time at the beginning of the study. After two days from injection, rats with blood glucose level above $250 \mathrm{mg} / \mathrm{dl}$ will be considered diabetic according to ${ }^{[9]}$.
Diabetic rats were then divided into 4 subgroups as follows:

\subsection{Diabetic Untreated group (DG):}

In which Ten diabetic rats remained untreated.

\subsection{The Insulin treated group (IG):}

In which ten diabetic rats were administered a subcutaneous injection of insulin at a dose of 2 U \ratlday for 21 days $^{[10]}$.

\subsection{The Garlic treated group (GG):}

Ten diabetic rats received an oral daily dose of garlic water suspension through a sterile oral feeding tube. (dried garlic powder $150 \mathrm{mg} / \mathrm{kg}$ body weight was mixed with $1 \mathrm{ml}$ of distilled water per day ${ }^{[5]}$. The treatment continued for 21 days $^{[11]}$.

\subsection{The Onion treated group $(\mathrm{OG})$ :}

Ten diabetic rats received an oral daily dose of onion water suspension through a sterile oral feeding tube. ( dried onion powder at a dose of $1.5 \mathrm{gm} \backslash$ ratlday was mixed with $1 \mathrm{ml}$ of distilled water). The treatment continued for 21 days $^{[6]}$.

\section{Monitoring of Blood Glucose Level}

Tail vein blood samples were obtained by a sharp cut 48 hours following STZ injection. The blood glucose level was measured using On Call Plus (Blood Glucose Test Strip, ACON Company). Then the blood glucose level was monitored weekly throughout the experiment period to detect if any improvement has been encountered.

\section{Samples preparation}

At the end of the experiment, rats of all experimental groups were anaesthetized then sacrificed separately, and their tongues were immediately dissected. The rest of rats' bodies were appropriately gotten rid of them in the incinerator of Ain - Shams Hospital. The collected specimens were equally divided and prepared for:

\section{A- Light microscopic examination:}

Half of the tongue specimens, were first dissected coronally at the posterior third of the tongue (just posterior to sulcus terminalis), to separate the circumvallate papillae, then the rest of the rat's tongue as a whole was dissected saggitally to examine the other papillae. The samples were fixed immediately in $10 \%$ formalin solution for not less than one week and then the specimens were washed properly under running water, dehydrated by transferring through increasing concentrations of alcohol $(50 \%, 60 \%$, $80 \%, 90 \%, 96 \%$, and absolute alcohol), then transferred to xylol to clear the specimen from alcohol. The tongues were then impregnated in paraffin wax and embedded in the center of paraffin wax blocks. The embedded specimens were sectioned by microtome (4 microns thick), the sections were transferred in decreasing concentrations of alcohol (96\%, 70\%, then distilled water). Finally, the sections were stained by Hematoxylin and Eosin (H\&E) stain ${ }^{[12]}$ and were examined by light microscope. 


\section{B- Scanning electron microscopic examination:}

The other half of tongue specimens (including the circumvallate in coronal sections, and sagittal sections of the whole tongue) were kept in a $2.5 \%$ glutaraldehyde fixative in $0.1 \mathrm{M}$ buffered phosphate solution (PH: 7.4). The samples were rinsed in $0.1 \%$ phosphate buffer for 3 hours and then were post-fixed in osmium tetroxide for 15 minutes. The traces of unbound osmium were rinsed with two changes of $0.1 \%$ phosphate buffer. The fixed samples were dehydrated by sequential ascending dehydration process with ethanol $50 \%, 60 \%, 70 \%, 80 \%, 90 \%$ and $100 \%$ for 10 minutes for each concentration. Then, the ethanol was replaced with carbon dioxide at high pressure by critical point dryer (CPD030 Bal Tec Company, UK).

After fixation, samples were cut to the appropriate size to fit in the sample chamber. The investigated samples were mounted rigidly on specimen stubs using double-sided adhesive carbon tape. The samples were gold coated (by - Super Cool sputter coater (SCD-050, Bal Tec Company, UK)) before examination in the microscope because gold has a high atomic number and the sputter coating with gold produces high topographic contrast and resolution. The dorsal surface of tongue specimens was examined by scanning electron microscope (Philips XL30, Netherlands) operated at $30 \mathrm{KV}$. All scanning electron microscopic (SEM) examinations were achieved in Parasitology department, Faculty of Medicine, Al-Azhar University, Egypt.

No statistical analysis was performed in this study as we aimed mainly to shed light on the apparent histological and morphological changes occurring in tested groups.

\section{RESULTS}

The average blood glucose levels for each group of rats before the start of the experiment ranged from 100$120 \mathrm{mg} / \mathrm{dl}$. After 48 hours of STZ treatment, the average blood glucose levels of the diabetic rats ranged from 378 to $550 \mathrm{mg} / \mathrm{dl}$ and the diabetic rats showed cardinal signs of polyphagia, polydipsia and polyurea.

The mean body weight for all groups before STZ treatment ranged from 200-250 gm.

\section{Light Microscopic Results}

\section{1) Control Group (CG)}

\section{Filiform Papillae}

Examination of the (H\&E) stained sections of the dorsal surface of the control tongues revealed evenly distributed filiform papillae regular in size, shape and orientation with normal keratinized stratified squamous epithelium covering.

Three types of filiform papillae were detected. They all have stratified squamous epithelium with thin regular layer of orthokeratin covering showing convex and concave sides. The lamina propria showed normal histological structure, with secondary papillae (Figure 1)

\section{Fungiform Papillae}

The papillae showed the characteristic mushroom shape and appeared elevated above the surface of the tongue. They were found scattered in between filiform papillae. These papillae were covered by keratinized stratified squamous epithelium. A single well-defined barrel-shaped taste bud was observed on the dorsal surface. The lamina propria was formed of CT core of normal histological structure with short secondary papillae (Figure 2).

\section{Circumvalate Papillae}

They appeared as single inverted cone, not projecting above the surface of the tongue and surrounded by a welldeveloped deep, narrow trough. It was covered by a thin layer of orthokeratinized stratified squamous epithelium of even thickness on its dorsal surface as well as the sides of the trough. Ducts of the pure serous minor salivary glands (Von Ebner) were observed opening in the depth of the trough. Numerous taste buds were present in the epithelial wall of the trough showing normal shape and distribution. Lamina propria of dense $\mathrm{CT}$ was observed with numerous secondary papillae (Figure 3).

\section{2) Diabetic Groups}

\subsection{Diabetic Untreated Group (IG)}

\section{Filiform Papillae}

Examination of (H\&E) stained sections of this group revealed that some of the filiform papillae lost their characteristic flame-like appearance and appeared short with rounded tips. They were covered by torn and separated orthokeratinized layer. Many epithelial cells showed intracellular vacuolations. The lamina propria was thin, loose and edematous and inflammatory cells infiltrate was evident in CT of those papillae. Hyalinization and degeneration of CT could be seen. There were no obvious secondary papillae. Some of the papillae were noticeably disfigured with separation and loss of characteristic keratin configuration (Figure 4).

\section{Fungiform papilla}

The fungiform papillae lost their characteristic appearance and appeared as rounded projections with narrow dorsal surface and wide base. The papillae were covered by thin orthokeratinized stratified squamous epithelium with thin keratin layer. Numerous intra-epithelial cell vacuolations were detected. The taste bud cells appeared to be shrunken with distorted cellular outlines as the taste bud showed peripheral arrangement of cells with empty center. The lamina propria was loose and edematous (Figure 5).

\section{Circumvallate papilla}

The circumvallate papillae revealed detached keratin layer, apparent discontinuity of epithelium and widening of the trough. Taste buds were distorted and fewer in number than those of the control group. The lamina propria showed 
some inflammatory cells and areas of degeneration of CT with dilated blood vessels (Figure 6).

\subsection{Insulin- treated group (I.G.)}

\section{Filiform papillae}

Examination of (H\&E) stained sections of simple filiform papillae of this group revealed:

some of them were shortened and disfigured with rounded tips. Rare cytoplasmic vacuolations were found (Figure 7).

\section{Fungiform papillae}

Fungiform papillae revealed well defined taste buds on its dorsum. A thin uniform layer of keratin could be seen on the most superficial epithelial layer (Figure 8).

\section{Circumvallate papillae}

The papilla appeared almost with well-defined taste buds but fewer in number than that of the CG. The C.T. showed presence of inflammatory cells (Figure 9).

\subsection{Garlic Treated Group (GG)}

\section{Filiform Papillae}

Examination of (H\&E) stained sections of filiform papillae of this group revealed evenly distributed papillae regular in size, shape and orientation with normal keratinized stratified squamous epithelium. The papillae appeared almost similar to those of control group, but with presence of some intracellular cytoplasmic vacuolations (Figure 10).

\section{Fungiform Papillae}

Fungiform papillae revealed normal mushroom shaped papilla with well-defined dorsal taste bud (Figure 11).

\section{Circumvallate Papilla}

Circumvallate papillae were covered by keratinized stratified squamous epithelium of even thickness and thin keratin layer with multiple secondary CT papillae. The trough appeared narrow, uniform and deep with welldefined numerous taste buds. The CT core showed some inflammatory cells (Figure 12).

\subsection{Onion Treated Group (O.G.)}

\section{Filiform Papillae}

Examination of (H\&E) stained sections revealed evenly distributed papillae regular in size, shape and orientation with normal keratinized stratified squamous epithelium covering (Figure13)

\section{Fungiform Papillae}

Fungiform papillae of this group appeared well formed, mushroom shaped, with well-defined dorsal taste bud. The epithelium was covered by uniform keratin layer and displayed no intra-epithelial cell vacuolations. The CT showed normal structure with rare inflammatory cells (Figure14).

\section{Circumvallate Papillae}

Circumvallate papillae appeared inverted cone, surrounded by narrow deep trough. Most of taste buds were well defined and seen on the walls of the trough. The CT displayed normal histological appearance with rare or no inflammatory cells (Figure 15).

\section{Scanning Electron Microscopic Results}

\section{1) Control Group (CG)}

\section{Filiform Papilla}

Examination of tongues of C.G. revealed that filiform papillae were covering the majority of the dorsal tongue surface.

Simple conical filiform papillae: appeared as numerous conical projections with uniform pointed keratinized tips and smooth surface. They were arranged in parallel rows with regular antero-posterior direction curving backward towards the tongue root (Figure 16)

\section{Fungiform papilla}

They were randomly distributed in between filiform papillae particularly on the anterior and middle regions. The papillae appeared cauliflower in shape with well obvious surface keratin scales and visible well-defined regular taste pore which appeared depressed in the central region and surrounded by a shallow indention (Figure17).

\section{Circumvallate Papilla}

Circumvallate papillae showed central papillary structure with tapered end, micro ridges on its surface and surrounded with horse shoe elevated flanking papillary structure and trough (Figure 18).

\section{2) Diabetic Groups}

\subsection{Diabetic Untreated Group:}

\section{Filiform Papillae}

Simple conical filiform papillae showed disturbed orientation and inclination. Most of them showed keratinized pointed ends with constricted keratin covering and some were bifid (Figure 19).

\section{Fungiform papilla}

The papillae of this group were shrunken in size with disappearance of keratin scales. The gustatory pore appeared very narrow. Also, it was noticed that the surrounding filiform papillae were fewer in number than in control group. (Figure 20).

\section{Circumvallate Papilla}

Circumvallate papilla was disfigured with areas of distorted papillary ridges. The trough was evidently wide and of uneven width. (Figure 21). 


\subsection{Insulin Treated Group (IG)}

\section{Filiform Papillae}

Filiform papillae showed narrow uniform keratinized tips arranged in parallel rows with regular antero-posterior direction curving backward towards the tongue root (Figure 22).

\section{Fungiform Papilla}

Fungiform papillae revealed no obvious keratin scales, and visible taste pore in a central depressed region (Figure 23)

\section{Circumvallate Papillae}

Circumvallate papillae showed almost normal central papillary part with obvious micro ridges, but irregular flanking part and uneven width of the trough (Figure 24)

\subsection{Garlic Treated Group (GG)}

\section{Filiform Papillae}

Simple conical filiform papillae were with uniform keratinized tapered tips arranged in parallel rows with regular antero-posterior direction curving backward towards the tongue root (Figure 25).

\section{Fungiform Papillae}

The papillae showed characteristic cauliflower appearance with depressed central region and visible taste pore (Figure 26).

\section{Circumvallate Papillae}

The papillae revealed triangular central papillary structure with tapered end, micro ridges on its surface and surrounded by narrow trough of uniform width (Figure 27).

\subsection{Onion Treated Group (OG)}

\section{Filiform Papillae}

Filiform papillae were uniform with keratinized tips arranged in parallel rows with regular antero-posterior direction curving backward towards the tongue root. Their appearance greatly resembled that of the control group. (Figure 28)

\section{Fungiform Papillae}

Fungiform papillae revealed characteristic cauliflower shape with obvious well-defined regular taste pore which appeared depressed in the central region and surrounded by a shallow indention, which was almost identical to the appearance of the control group (Figure 29).

\section{Circumvallate Papillae}

The papillae revealed depressed central papillary part surrounded by narrow uniform trough, their image greatly resembled those of the control group (Figure 30).

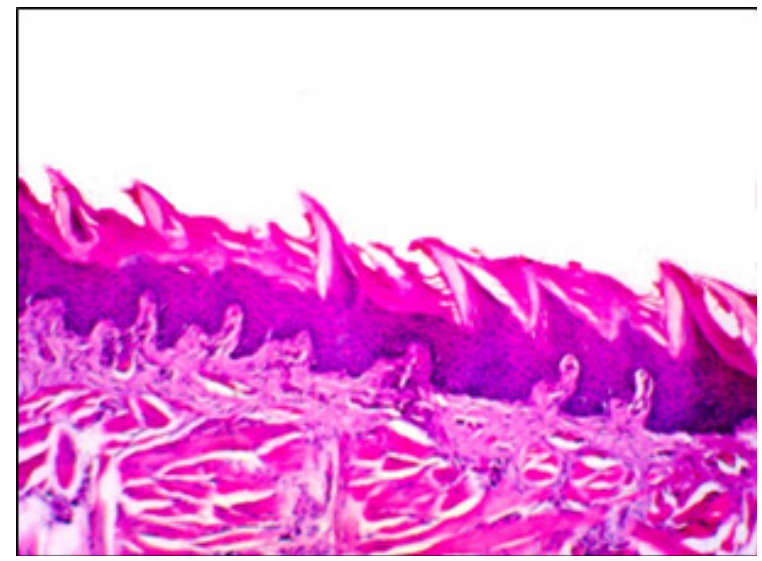

Fig. 1: A photomicrograph of the dorsum of the tongue of a rat from the CG showing evenly distributed filiform papillae regular in size, shape \& orientation with normal orthokeratinized epithelial covering and normal CT (H\&E x100)

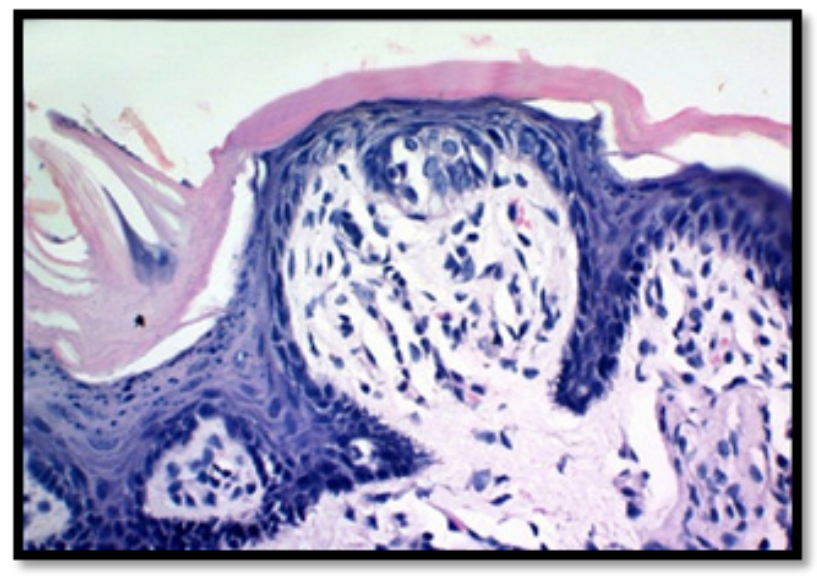

Fig. 2: A photomicrograph of the dorsum of the tongue of a rat from the $C G$ showing a mushroom shaped fungiform papilla with a single well-defined taste bud (Yellow arrow) (H\&E x400)

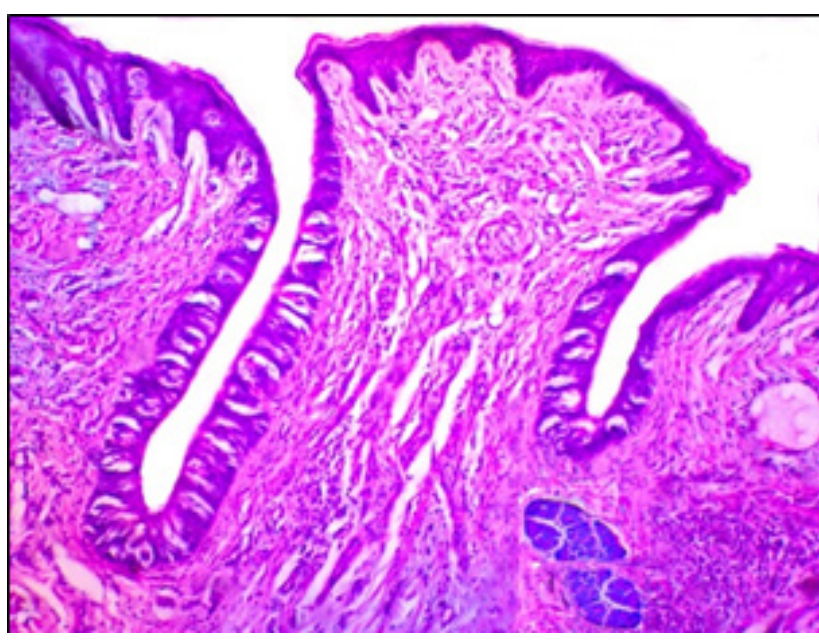

Fig. 3: A photomicrograph of the the dorsum of the tongue of a rat from the CG showing circumvallate papilla with a narrow trough and numerous taste buds present in the trough wall (yellow arrows). Von Ebner Salivary glands could be detected close to the trough (black arrow) (H\&E x100) 


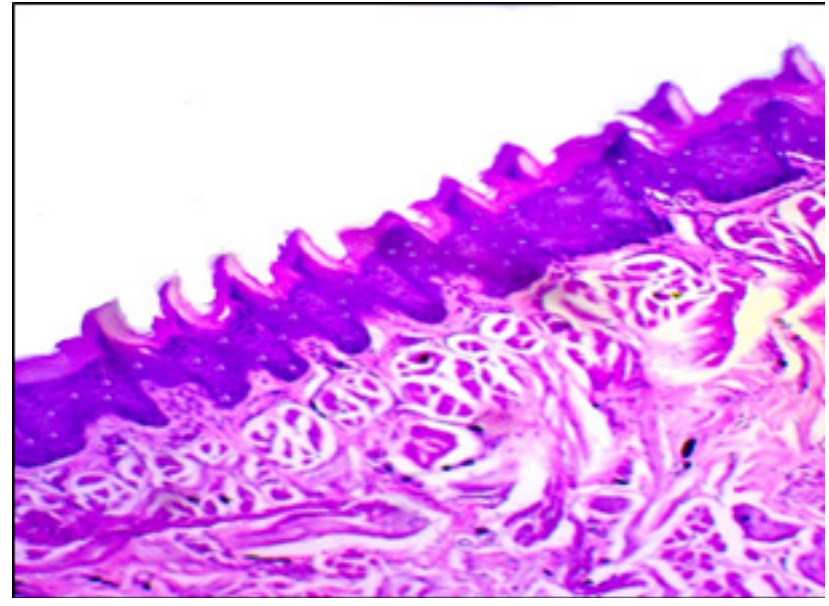

Fig. 4: A photomicrograph of the dorsum of the tongue of a rat from the DG showing shortened filiform papillae with rounded tips. Areas of intraepithelial cytoplasmic vacuolations (arrows), loose edematous C.T. papillae and disappearance of most of secondary papillae (H\&E X100)

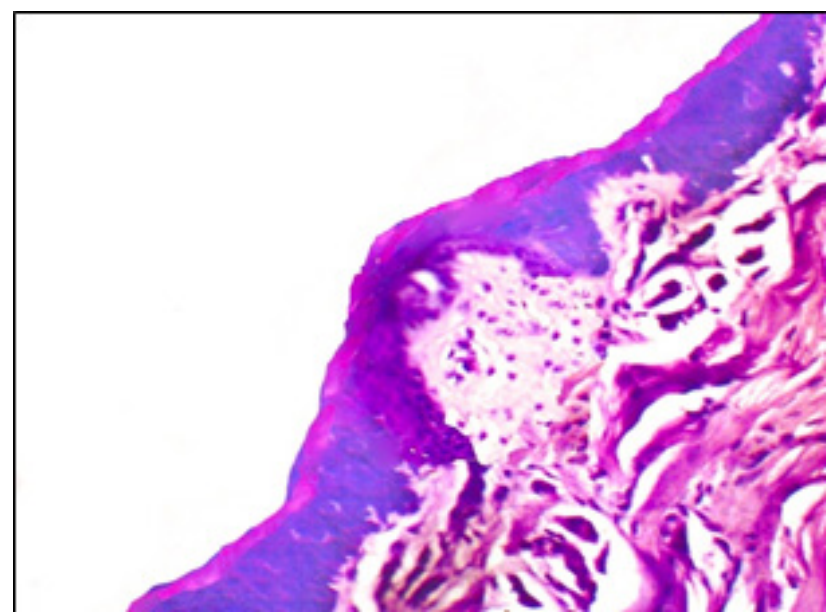

Fig. 5: A photomicrograph of the dorsum of the tongue of a rat from the DG showing a disfigured fungiform papilla, with numerous intra-epithelial cell vacuolations (black arrow), distorted taste bud (yellow arrow) and loose edematous CT (H\&E x200)

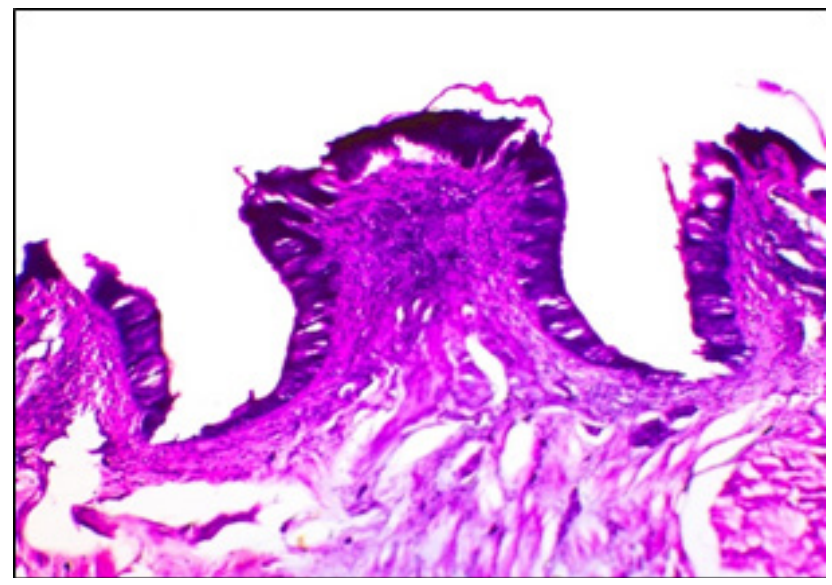

Fig. 6: A photomicrograph of the dorsum of the tongue of a rat from the DG showing circumvallate papilla with detached keratin layer, discontinuous epithelium and widened trough, few distorted taste buds on the trough wall(arrows), extracellular edema in CT with dilated blood vessels. (H\&E x100)

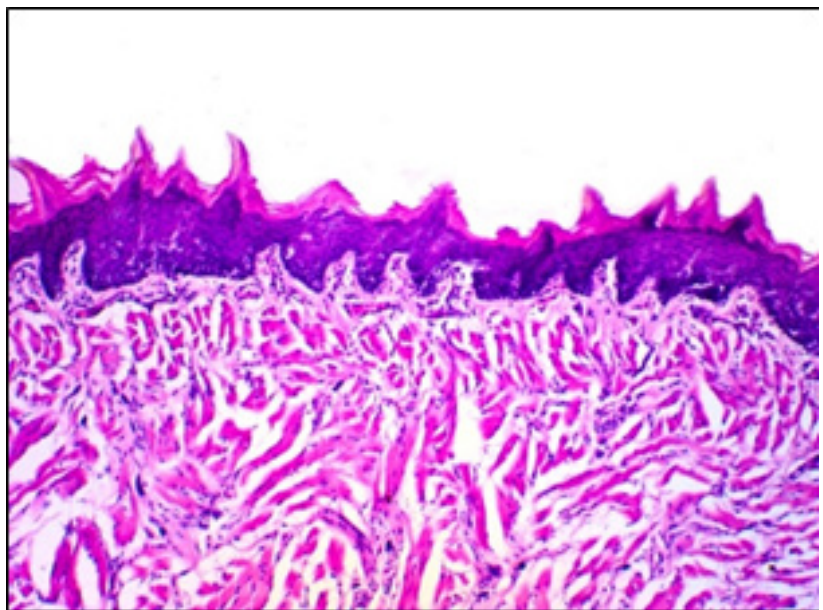

Fig. 7: A photomicrograph of the dorsum of the tongue of a rat from the IG showing filiform papillae with areas of thinning in epithelial covering and keratin layer, few cytoplasmic vacuolations (arrow) (H\&E x100)

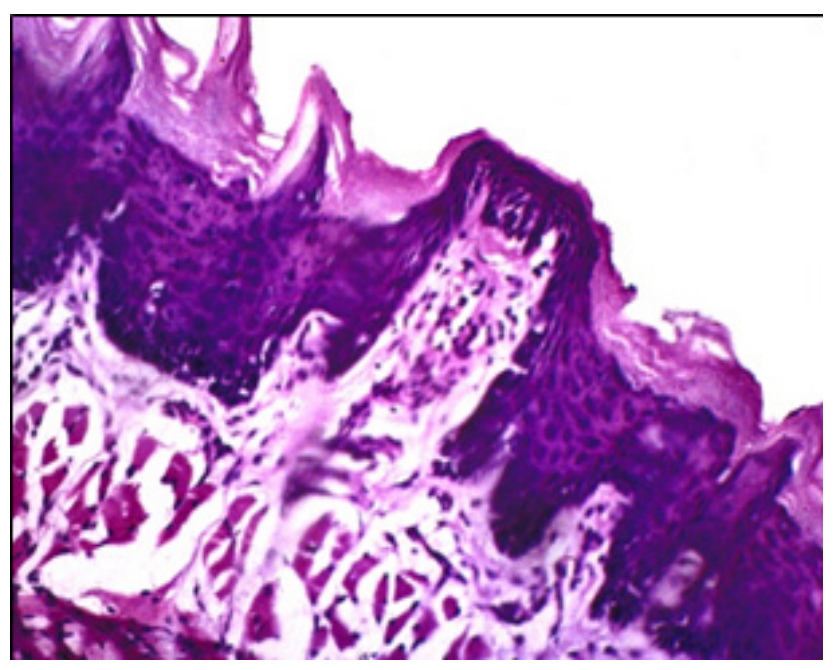

Fig. 8: A photomicrograph of the dorsum of the tongue of a rat from the IG showing fungiform papilla with well-defined taste bud cells (arrow) (H\&E $\mathrm{x} 200)$

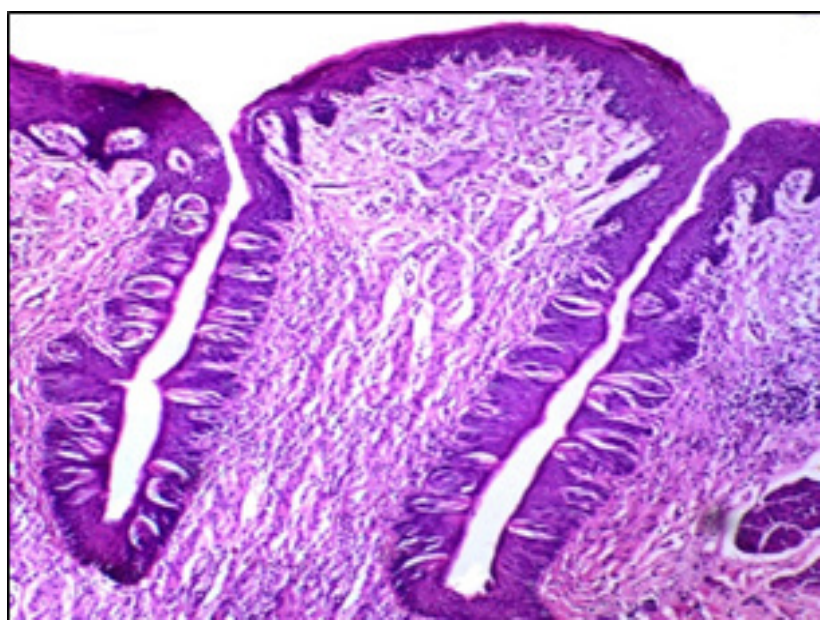

Fig. 9: A photomicrograph of the dorsum of the tongue of a rat from the IG showing circumvallate papilla with narrow trough, numerous tastes buds on the trough walls, and some inflammatory cells in the C.T.(arrows) (H\&E $\mathrm{x} 100)$ 


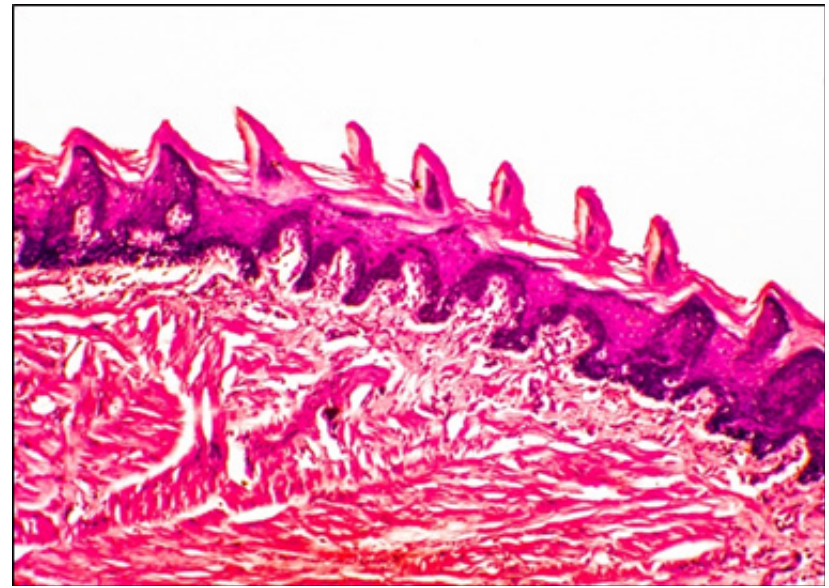

Fig. 10: A photomicrograph of the dorsum of the tongue of a rat from the GG showing simple conical filiform papillae which were regular in size, shape \& orientation with normal orthokeratinized epithelial covering and well-formed secondary CT papillae. Some intra-epithelial cell vacuolations could be seen (arrow) (H\&E x100)

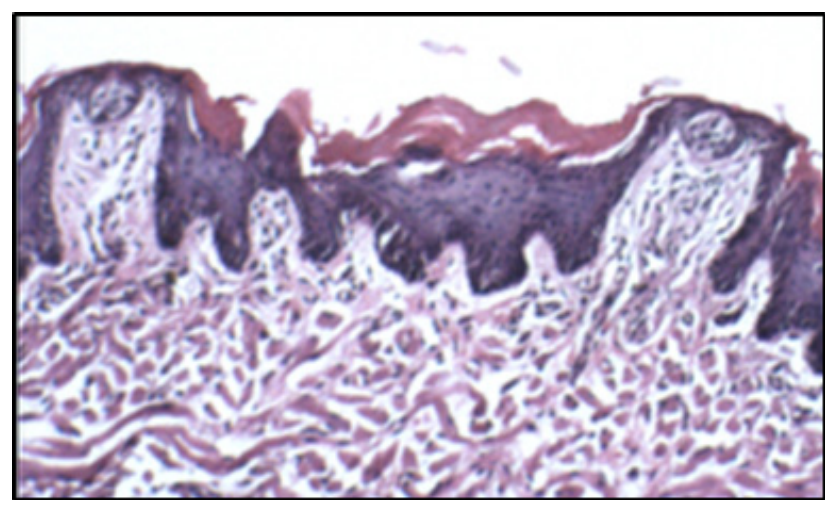

Fig. 11: A photomicrograph of the dorsum of the tongue of a rat from the GG showing well-developed fungiform papillae covered by thin uniform layer of keratin with well-defined taste bud (arrows)(H\&E X200)

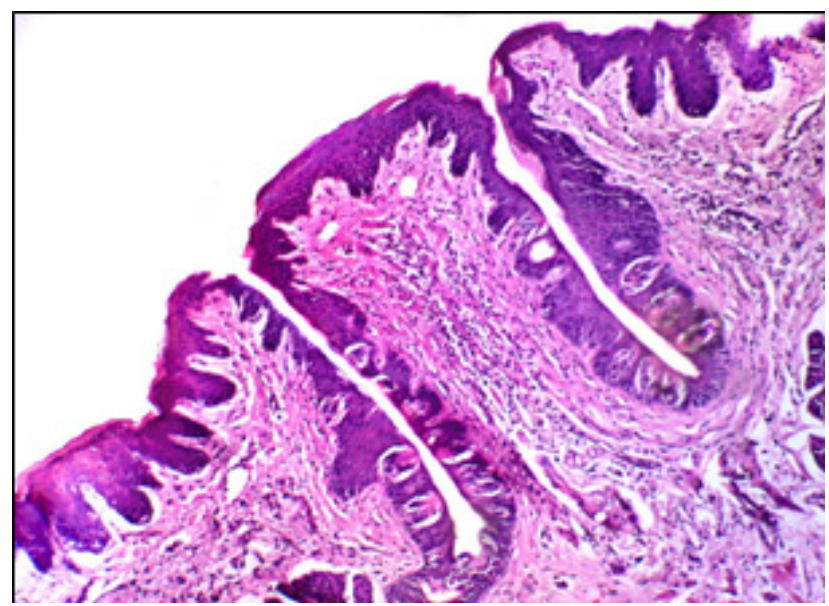

Fig 12: A photomicrograph of the dorsum of the tongue of a rat from the GG showing circumvallate papilla with narrow deep trough, numerous taste buds on trough walls and some inflammatory cells in the CT. (arrow)(H\&E $\mathrm{x} 100)$

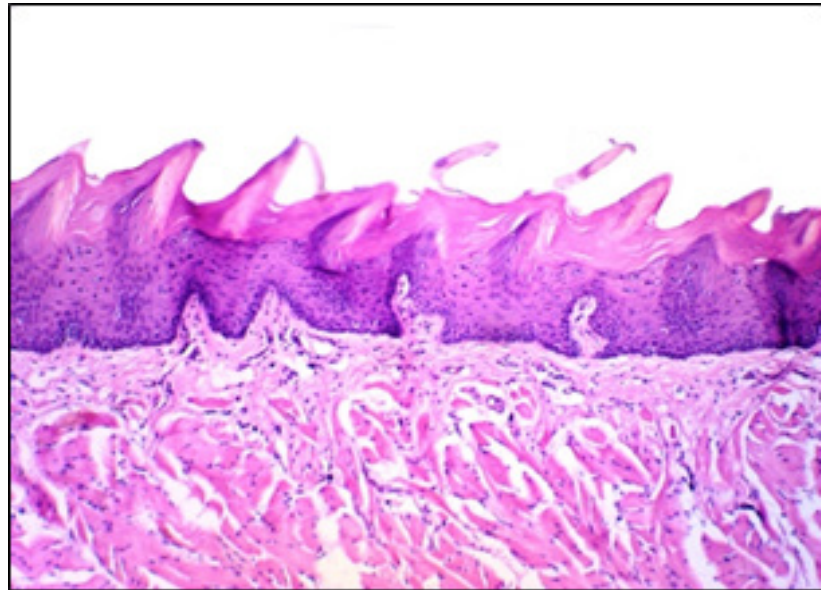

Fig. 13: A photomicrograph of the dorsum of the tongue of a rat from the OG showing simple conical filiform papillae regular in size, shape $\&$ orientation with normal orthokeratinized epithelial covering and wellformed secondary CT papillae (H\&E x100)

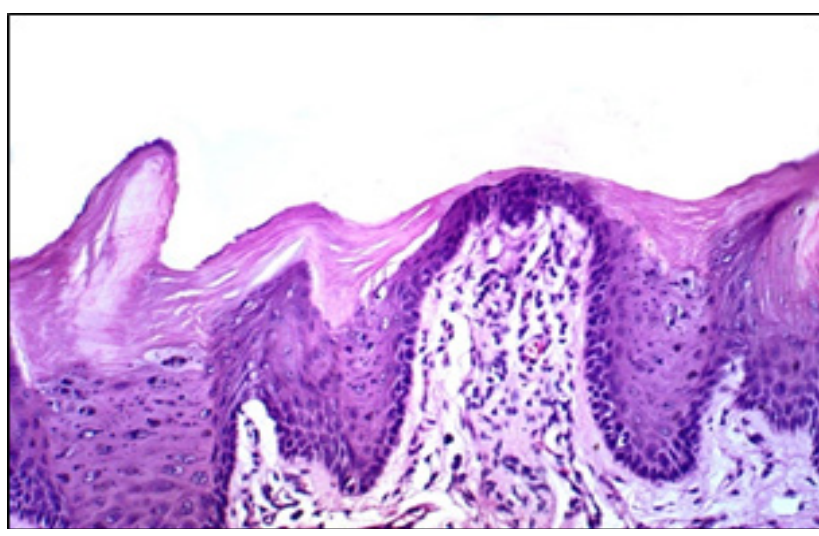

Fig. 14: A photomicrograph of the dorsum of the tongue of a rat from the OG showing a mushroom shaped fungiform papilla with well-defined dorsal taste bud (arrow), almost no intra-epithelial cell vacuolations were detected. (H\&E x200)

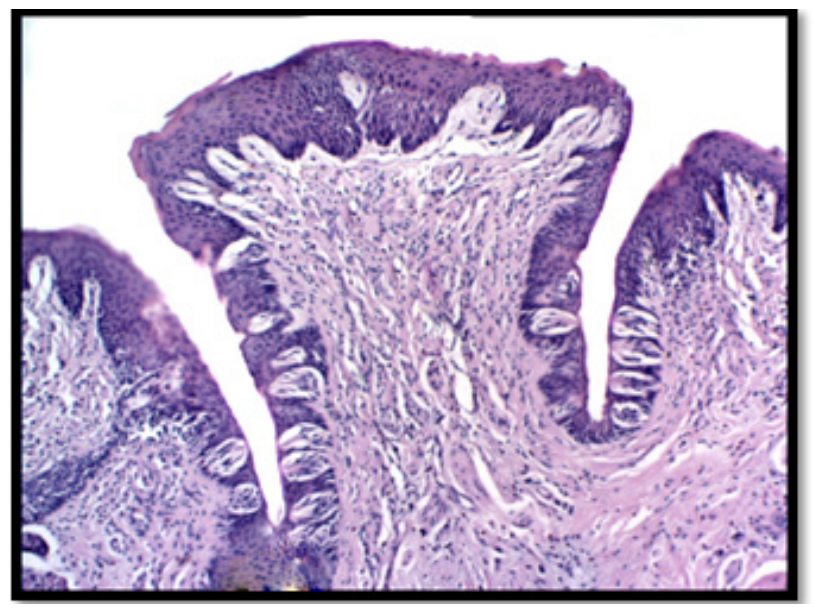

Fig. 15: A photomicrograph of the dorsum of the tongue of a rat from the OG showing inverted-cone shaped circumvallate papilla with narrow deep trough and numerous well-formed taste buds, well-formed CT and secondary CT papillae with rare inflammatory cell infiltrate.(H\&E X100) 


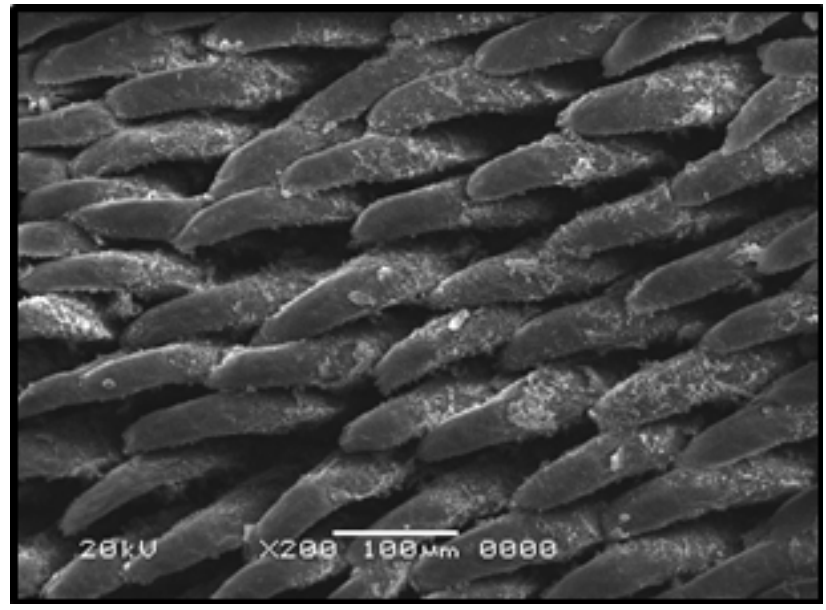

Fig. 16: A scanning electron micrograph of the dorsum of the tongue of a rat from the CG showing simple conical filiform papillae with uniform keratinized tips arranged in parallel rows with regular antero-posterior direction curving backward towards the tongue root (x200)

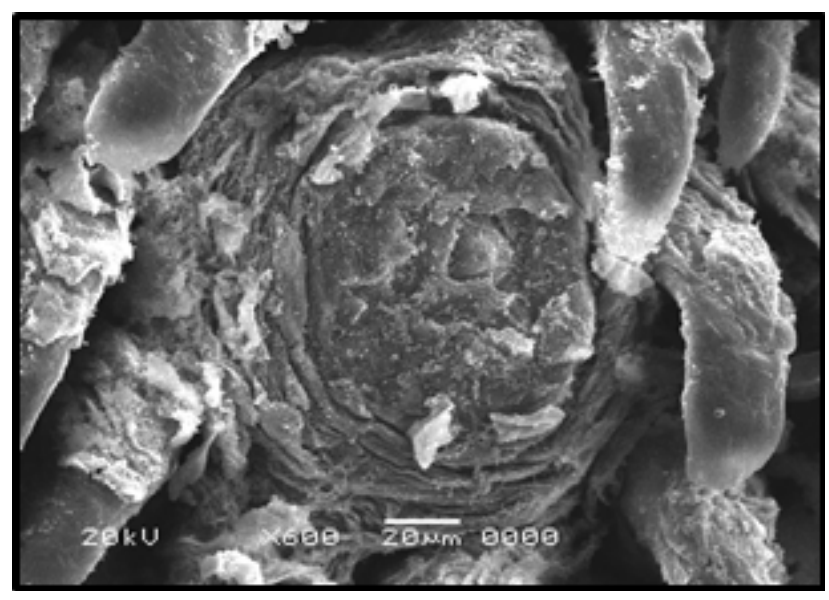

Fig. 17: A scanning electron micrograph of the dorsum of the tongue of a rat from the C.G. showing fungiform papilla appeared cauliflower in shape with obvious surface keratin scales and visible well-defined taste pore with depressed center and surrounded by a shallow indention (x600)

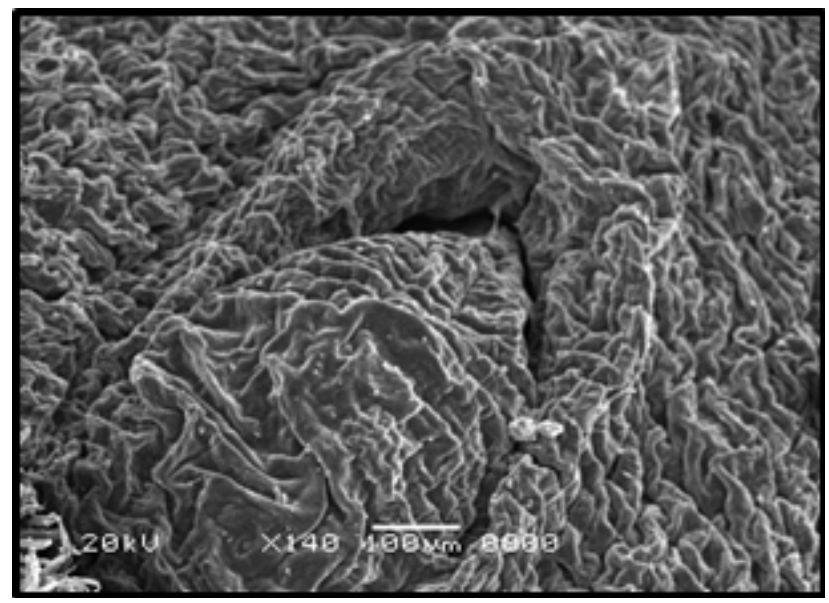

Fig. 18: A scanning electron micrograph of the dorsum of the tongue of a rat from the CG showing circumvallate papilla as central papillary structure with tapered end, micro ridges on its surface surrounded with horse shoe flanking papillary structure and trough (x140)

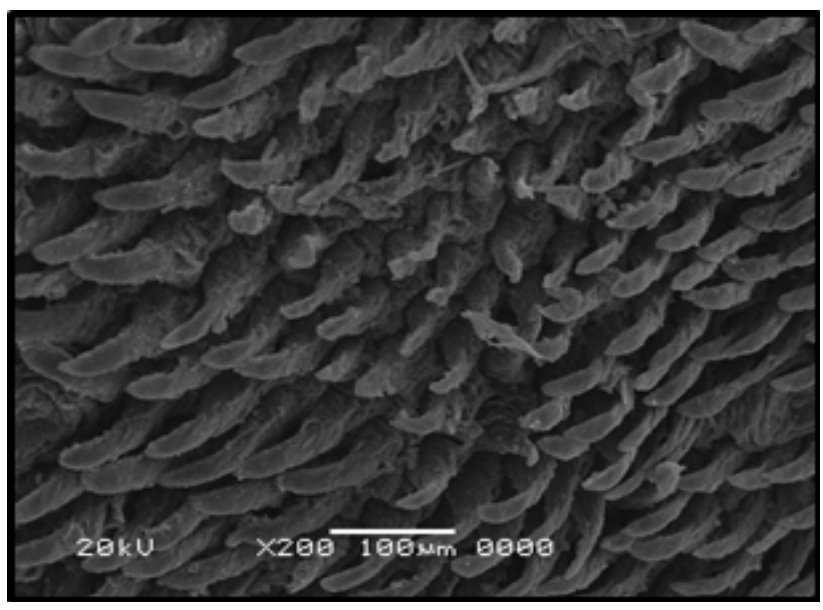

Fig. 19: A scanning electron micrograph of the dorsum of the tongue of rat from the DG showing some disfigured simple conical filiform papillae with disturbed orientation and inclination. Most of them show keratinized pointed ends with constricted keratin covering and some were bifid (arrows) (x200)

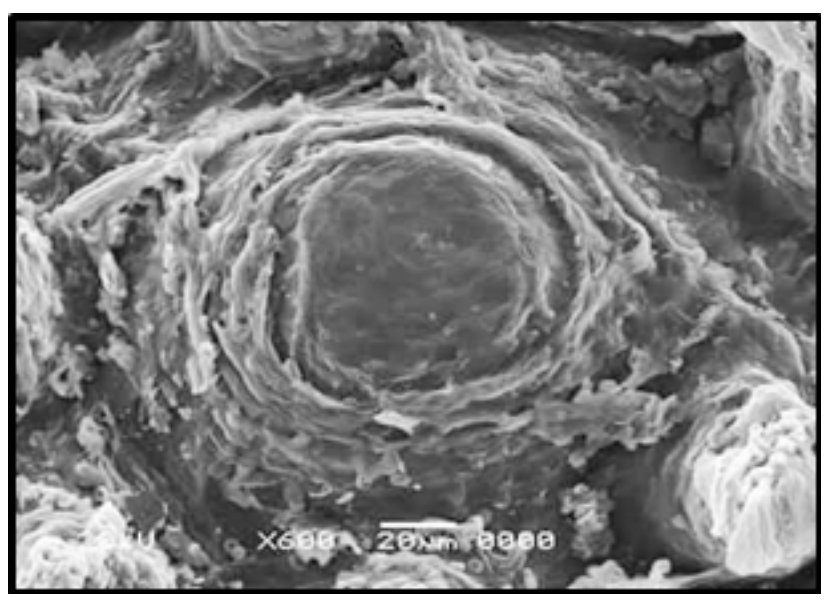

Fig. 20: A scanning electron micrograph of the dorsum of the tongue of a rat from the DG showing fungiform papilla with very narrow gustatory pore and no obvious keratin scales. (x600)

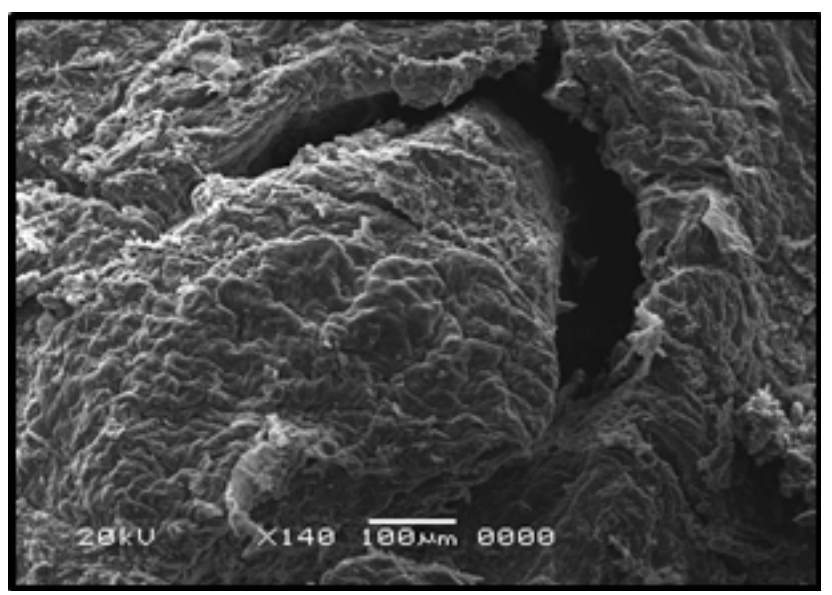

Fig. 21: A scanning electron photomicrograph of the dorsum of the tongue of a rat from the DG showing disfigured circumvallate papilla with area of distorted papillary ridges. The trough was evidently wide and distorted (x140) 


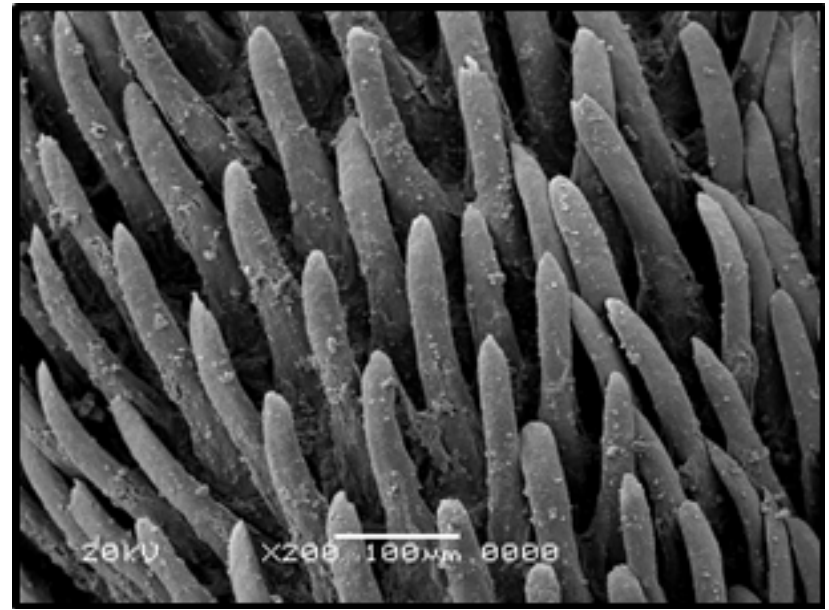

Fig. 22: A scanning electron micrograph of the dorsum of the tongue of a rat from the IG showing filiform papillae with regular antero-posterior direction $(\mathrm{x} 200)$

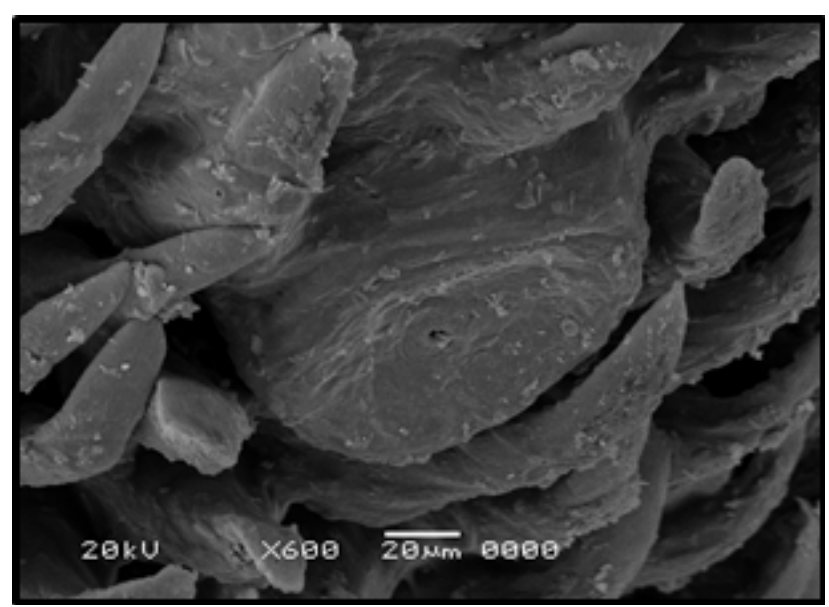

Fig. 23: A scanning electron micrograph of the dorsum of the tongue of a rat from the IG showing fungiform papilla with no obvious keratin scales, and visible taste pore in a central depressed region (arrow) (x600)

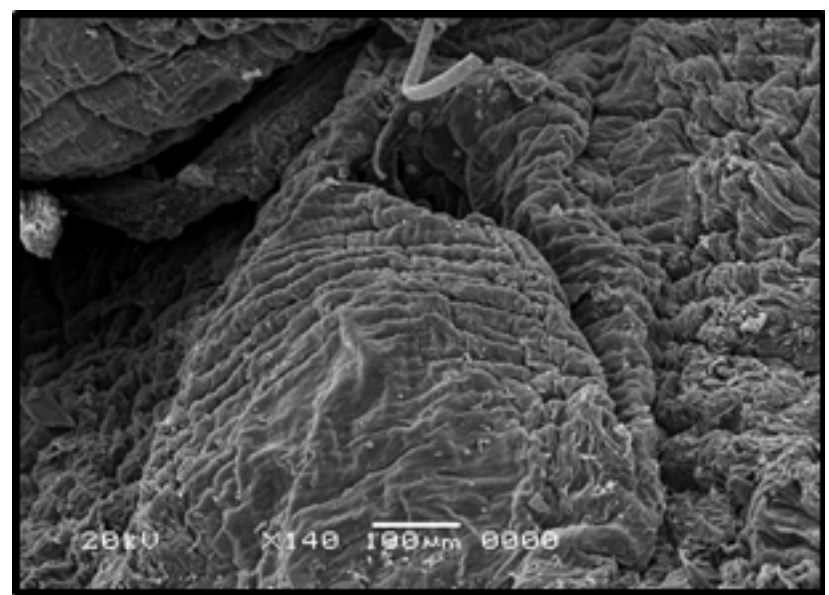

Fig. 24: A scanning electron micrograph of the dorsum of the tongue of a rat from the IG showing circumvallate papillae with almost normal central papillary part and uneven width of the trough (x 140)

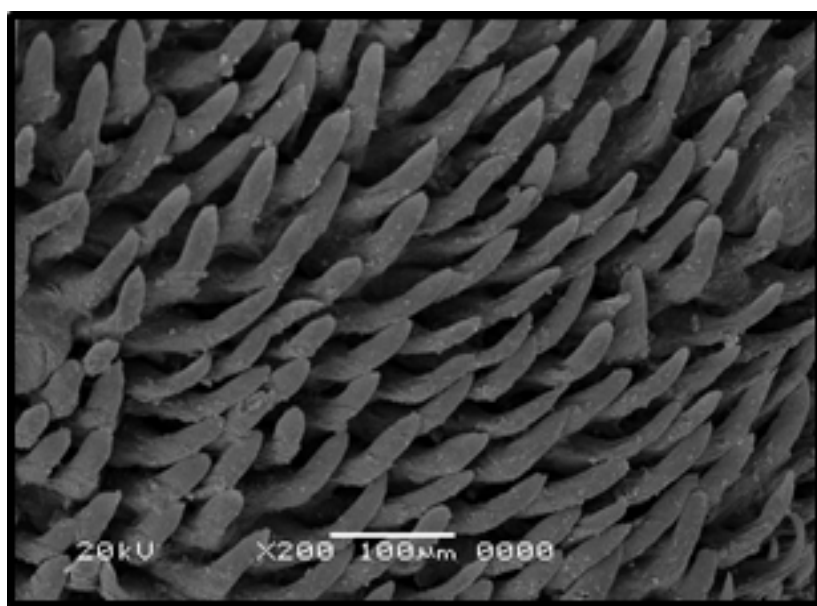

Fig. 25: A scanning electron microscope of the dorsum of the tongue of a rat from the GG showing simple filiform with regular antero-posterior direction and tapered tips (x200)

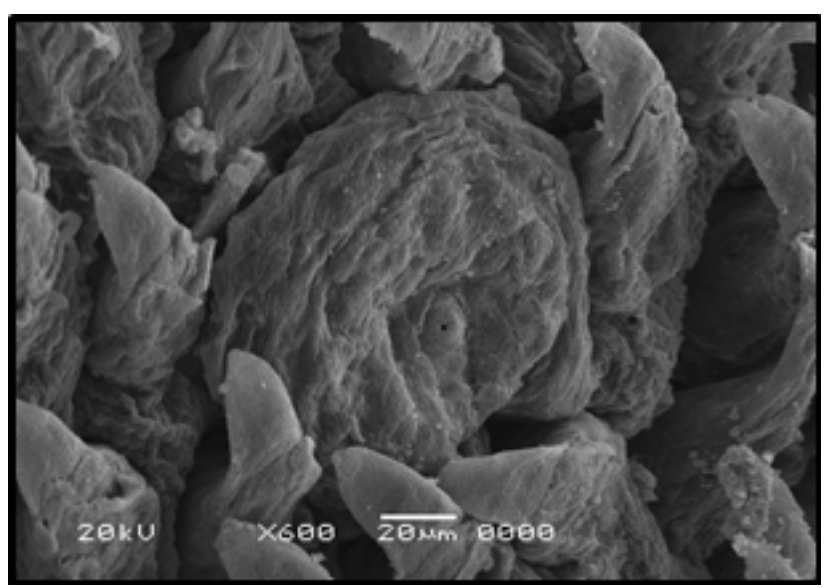

Fig. 26: A scanning photomicrograph of the dorsum of the tongue of a rat from the GG showing characteristic cauliflower appearance of fungiform papilla with depressed central region and visible taste pore (arrow) (x 600)

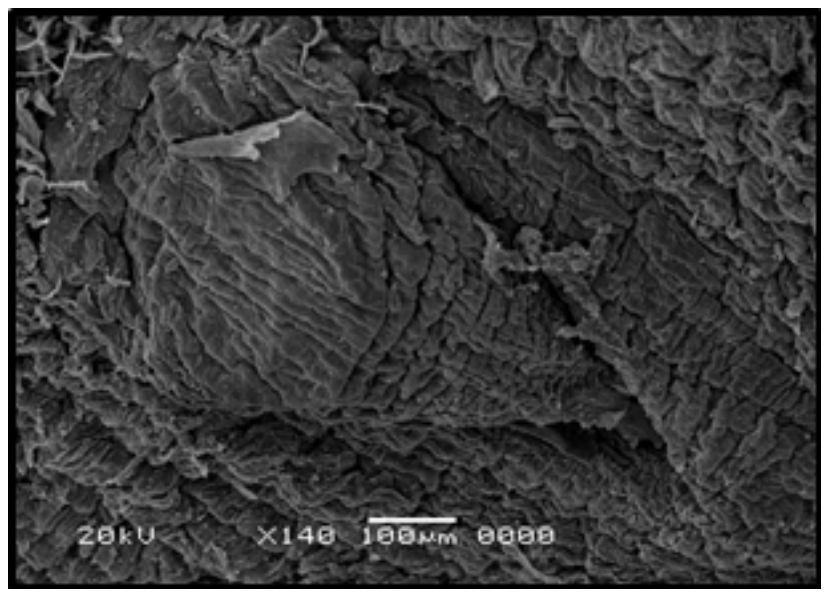

Fig. 27: A scanning electron micrograph of the dorsum of the tongue of a rat from the GG showing triangular central papillary structure with tapered pointed end, micro ridges on its surface and surrounded by narrow trough of uniform width. (x140) 


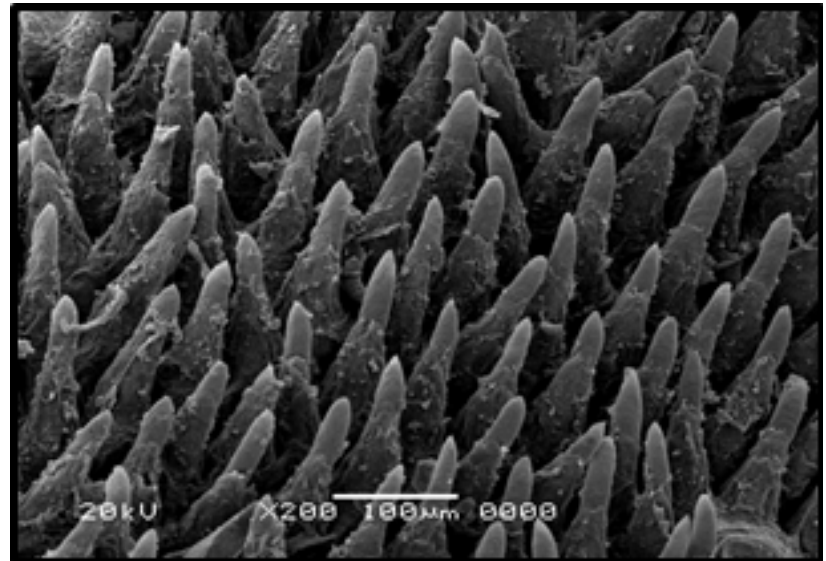

Fig. 28: A scanning electron microscope of the dorsum of the tongue of a rat from the OG showing filiform with regular antero-posterior direction and narrow tips (x200)

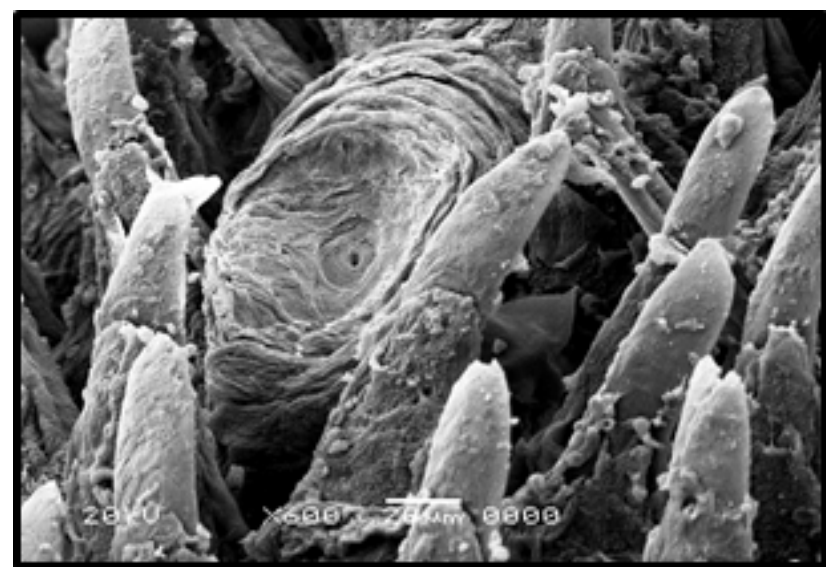

Fig. 29: A scanning electron micrograph of the dorsum of the tongue of a rat from the OG showing fungiform papilla with characteristic cauliflower shape and obvious well-defined regular taste pore (arrow) (x600)

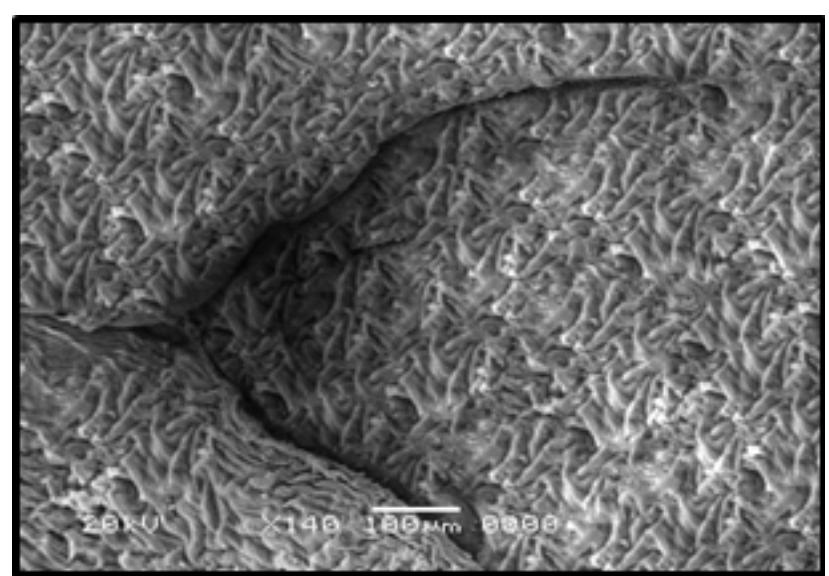

Fig. 30: A scanning electron micrograph of the dorsum of the tongue of a rat from the OG showing circumvallate papilla with depressed central papillary part surrounded by narrow uniform trough (x 140)

\section{DISCUSSION}

Despite the understanding about the usefulness of insulin in the management of DM, for obvious reasons (such as availability, poverty, and proper storage), there has been unending efforts in searching for substitutes, either in synthetic forms or from plant sources, for the treatment of DM.

The search for safer and more effective drugs to reduce diabetic complications, is directed towards herbal therapy. Medicinal plants continue to provide valuable therapeutic agents, both in the modern and the traditional system. It is fascinating to observe how cultures that never came into contact with one another came to the same conclusions about the role of onions (Allium cepa) and garlic (Allium sativa) in health and disease states ${ }^{[13]}$.

The present study was carried out to assess the possible effect of onion and garlic in reducing diabetes complications and to compare their apparent effects with those of insulin intake on tongue structures.

Wistar Albino rats were chosen as the experimental animals because of their convenient handling and availability. Tongue was chosen to assess the effects of DM on tongue papillae and taste buds, which will be reflected as changes in taste sensation. Induction of experimental DM was done in our study by STZ as it has more advantages over alloxan such as sustained hyperglycemia and the development of well characterized diabetic complications with a low incidence of ketosis and mortality ${ }^{[14]}$.

Our results showed that control rats continued to grow normally throughout the experimental period with normal blood glucose level $110 \mathrm{gm} / \mathrm{dl}$ and increasing in weight from a mean of $215 \mathrm{gm}$ to $325 \mathrm{gm}$. Similar findings were reported by EBOMOYI et al., ${ }^{[15]}$, who related increase in body weight to substantial growth of rats by age. Also, histological and SEM examination of papillae revealed normal histology, shape and orientation. On the other hand, the diabetic rats, decreased significantly in weight from mean of $250 \mathrm{gm}$ to a mean of $150 \mathrm{gm}$. This decrease in body weight can be attributed to the polyurea and disturbance in carbohydrate metabolism accompanied with DM.

These findings coincide with KHALAF and GEHAN ${ }^{[16]}$ who found that, the body weight of the control rats in their study was significantly increased by $57 \%$ after 8 weeks, whereas the diabetic rats showed decrease in their body weight at the end of the experiment.

Histological results of the current study of untreated diabetic group, showed loss of characteristic flame-like appearance of filiform papillae as they were shortened with rounded tips and many epithelial cells showed intracellular vacuolations, separation and loss of characteristic keratin configuration. The lamina propria was thin, loose and edematous and inflammatory cells infiltrate was evident in $\mathrm{CT}$ of those papillae. Hyalinization and degeneration of CT could also be seen. The presence of cytoplasmic vacuolations in the epithelial cells of filiform papillae of untreated diabetic rats could be related to lysosomal damage and mitochondrial disturbance occurring with diabetes as reported by MACIEJEWASKI et al, ${ }^{[17]}$ who observed mitochondrial damage and swollen lysosomes in acinar cells 
of salivary glands in response to elevated blood glucose levels in rats with induced diabetes. The separation of keratin layer in almost all types of papillae might be caused by effect of increased blood glucose level on the desmosomal junction between epithelial cells. ATISOOK et al.,$^{[18]}$ reported that increased glucose level alters tight junction structure and diminishes tight junction resistance in the absorptive cell of the epithelium of the small intestine.

Dilated and congested blood vessels were observed mainly in the lamina propria of circumvallate papillae. This may be accounted for the effect of diabetes on microvasculature in the connective tissue. This came in accordance with RAND et al. ${ }^{[19]}$ who stated that, diabetes causes microvasculature damage as a result of poor glycemic control resulting in inhibition of normal function of endothelial cells.

Inflammatory cell infiltration was observed in the lamina propria. This is due to the inflammatory response caused by diabetes which resulted in release of inflammatory mediators that attracted inflammatory cells to the site of inflammation. This is in accordance with SILVA et al., ${ }^{[20]}$ who observed that, induction of diabetes caused marked inflammatory changes affecting both gingival epithelium and underlying connective tissue.

The hyalinization of CT indicates defective collagen content, matching with the results of CRAIG, et al, ${ }^{[21]}$ who reported that DM significantly depresses collagen hydroxyproline content resulting in a marked reduction in collagen synthesis. The defective collagen content could be also attributed to enhanced stimulation of Matrix Metalloproteinases (MMPs) resulting from over production of Reactive Oxygen Species (ROS) that accompany DM ${ }^{[22,23]}$. The MMPs are zinc-dependent endopeptidases, that are capable of cleaving most of basement membranes and extracellular matrix components, including collagen, fibrin, laminin, and proteoglycans in the connective tissues ${ }^{[24]}$.

Fungiform papillae showed changes in their mushroom shape. They showed narrow dorsal surfaces and wide bases. This was in accordance with AKIYA et al., ${ }^{[25]}$ who attributed this to the degree of atrophic changes relative to the length of diabetic state. Also taste buds in these papillae were vacuolated depicting peripheral arrangement of the cells and empty center. This finding with coincident with MOHAMED, ${ }^{[26]}$.

There was a variation in the degree of affection between different types of gustatory papillae expressed as few taste buds with shrunken cells and ill-defined cellular outlines. Taste buds are highly dependent on innervations for maintenance and function so these changes could be related to neuropathological changes of diabetes. This is supported by PAI et al. ${ }^{[27]}$ who found that, nerve fibers were attenuated on diabetes progression. Thus, taste impairment in diabetic subjects may be caused by neuropathy defect andlor morphological changes in taste buds. Circumvallate papillae were the most affected one as regard to morphology and histology of taste buds. This variation could be attributed to difference in their gustatory nerve supply. Our findings were in accordance with $\mathrm{CHOU}$ et al. ${ }^{[28]}$ who stated that intact innervations are essential for development and maintenance of gustatory papillae.

The histological results of Insulin treated group revealed that most of papillae had improved as filiform together with fungiform papillae were almost normal. Also circumvallate papillae showed well-formed taste buds but fewer than that of control group. This proves that insulin intake in early onset DM could improve the degenerative changes accompanying this ailment. Some inflammatory cells were seen in CT of circumvallate papillae.

The histological results of garlic and onion treated groups in our study showed that all types of papillae appeared almost normal by H\&E examination compared to control rats except that the onion group displayed apparently better histological and morphological appearance. The filiform papillae appeared regular in size, shape and orientation with almost normal CT. Fungiform papillae showed characteristic mushroom like appearance with well-defined dorsal taste bud. Gustatory papillae were almost normal with apparently fewer taste buds compared to control rats. This coincided with other studies that proved the antioxidant potential of garlic and onion ${ }^{[5,6]}$.

SEM examination of untreated diabetic group in our study coincided with (H\&E) results as it revealed deformative changes in the shape of tongue papillae, as filiform papillae were disfigured with narrow constricted tips. Also circumvallate papillae were shrunken, disfigured and showed wide trough. This can be interpreted as degenerative changes and evidences of apoptosis. These degenerative changes could be related to alteration in the lipid metabolism in various tissues due to DM, resulting in over production of ROS and creating a state of oxidative stress in various cells of the body ${ }^{[29]}$.

Also, these deformative changes were in agreement with that of MALHOTRA et al., ${ }^{[30]}$ who observed that STZinduced diabetes caused a significant disturbance in the properties of cytoskeletal components such as actin and myosin contractile proteins in cardiac muscle of diabetic rats, which could help explain their disfigured appearance.

SEM results of Insulin treated group showed almost normal filiform, as well as fungiform papillae. Circumvallate papillae appeared irregular with wide trough. The role of insulin in improvement of tongue papillae maybe explained by ROBINSON-WHITE and STRATAKIS ${ }^{[31]}$, who stated that, the active insulin receptor increase uptake of amino acids and glucose, activates protein synthesis from amino acids and glycogen and triglyceride synthesis from glucose. Insulin inhibits breakdown of triglycerides in adipose tissue and gluconeogenesis in the liver. A whole series of intracellular signal substances seemed to be responsible for the actions of insulin.

SEM results of garlic treated group coincided with (H\&E) results as all papillae appeared almost normal. So, we can claim that garlic administration had almost improved all types 
of papillae which can be explained by the hypoglycemic, antimicrobial, anti-inflammatory and immunomodulation effects of garlic. These finding coincide with a lot of studies. In-vivo as well as in-vitro studies showed that garlic acts as an insulin secretagogue in diabetic rats ${ }^{[32]}$.

Also, previous human studies had shown that chronic feeding of garlic oil and garlic powder produced a significant decrease in blood glucose level in diabetic patients ${ }^{[33]}$. The most probable mechanism for lowering fasting glucose was hypothesized by JAIN et al., ${ }^{[34]}$. They stated that allicin, which is the chief sulfur containing principle of garlic, combined readily with cysteine, glutathione, and serum albumin fractions, which combine with insulin and inactivate it, thus preventing the degradation of already available endogenous insulin. This also coincided with MAHESAR et al. ${ }^{[35]}$ who recorded significant decrease in elevated blood glucose levels diabetic rabbits when given garlic extract.

ALI et al., ${ }^{[36]}$ stated that the garlic oil-treated diabetic group in their study, was improved regarding histological parameters. This increased healing process may be linked to the anti-inflammatory, antimicrobial and immunomodulation effects of garlic oil and the inhibition of the inflammatory process resulting from the reduction in leukocyte adhesion and proinflammatory cytokines.

SEM results of onion treated group showed almost normal appearance of tongue papillae. This improvement was in agreement with ELDIN et al., ${ }^{[37]}$, who stated that the oral administration of Allium cepa crude hydroalcoholic extract in alloxan-induced diabetic rats produced a significant hypoglycemic activity and favorable good health effects, which may be most probably attributed to improvement and/or regeneration of pancreatic $\beta$-cells. Also, LEE et $a l .,^{[38]}$ investigated whether the onion juice could produce hypoglycemic activity in normal rats and antihyperglycemic effect in STZ induced diabetic rats. The results of their study indicated that onion (Allium cepa) had a beneficial anti-hyperglycemic effect in diabetes, thus minimizing the complications of DM.

\section{From our study, it can be concluded that}

- DM caused evident histological changes in tongue papillae especially gustatory ones thus impairment in taste sensation.

- Insulin administration caused effective improvement of tongue papillae.

- Garlic and onion oral intake caused valuable improvement of tongue papillae which was highly comparable to insulin treatment. Also, onion resulted in an apparently slightly better histological results that are comparable to control group.

- Also, few rats that were treated with garlic and onion showed decreased blood glucose level which means that they have a hypoglycemic effect.

- $\quad$ Based upon the previous study, the following could be recommended to protect diabetic patients from different diabetic complications especially taste impairment, it is recommended to increase dietary intake of garlic and onion in conjunction with insulin treatment.

- It could be mentioned that in poor regions of the world, with struggling economy and almost absent medical care, diabetic patients can still have the protection of onion and garlic, if used regularly in their diet.

\section{CONFLICTS OF INTEREST}

There are no conflicts of Interest

\section{REFERENCES}

1. ABEGUNDE D.O., MATHERS C.D., TAGHREED A., ORTEGON M. and STRONG K. The burden and costs of chronic diseases in low-income and middleincome countries. Lancet 2007; 370:1929-38.

2. Global Prevalence of Diabetes. Estimates for the Year 2000 and Projections for 2030. Geneva: World Health Organization (2009).

3. BAYNES J.W. Role of oxidative stress in development of complications in diabetes. Diabetes1991; 40: 405-412.

4. PELUSO M.R. Flavonoids attenuate cardiovascular disease, inhibit phosphodiesterase and modulate lipid homeostasis in adipose tissue and liver. Exp Biol Med (Maywood) 2006; 231 (8): 1287 - 99

5. MARCELAA.V., ROXANA E.G., NICOLAS F. R., CLAUDIO R. G. and ROBERTO, M.M. Aqueous garlic extracts prevent oxidative stress and vascular remodeling in an experimental model of metabolic syndrome. 2010: 58; (11): 6630-6635.

6. TSANG-HAI H., ROMAN C. MÜHLBAUER g., CHIH-HSIN T., HSIUN-ING C., GUAN-LIANG C., YI-WEI H., Yu-TING L., HSIN-SHI L., W EI-TING Y. and RONG-SEN Y. Onion decreases the ovariectomy-induced osteopenia in young adult rats. Bone 2008; 42: 1154-1163.

7. GUPTA R. \& GUPTA R.S. Effect of Pterocarpus marsupium in streptozotocin induced hyperglycemic state in rats: comparison with glibenclamide. Diabetol Croat 2009; 38: 39-45.

8. DAWSON RMC., ELLIOT DC., ELLIOT WH \& JONES KM. Data for Biochemical Research; Oxford Science Publ (1986); 3rd ed.

9. ANDERSON LC. \& GARRETT JR. The effect of streptozotocin induced diabetes on Norepinephrine and cholinergic enzymatic activities in rat parotid and submandibular gland. Arch. Oral Biol. 1994;39(2):91-97 
10. SHIJU M., RAJESH N. \& PRAGASAM V. Effect of long acting insulin supplementation on diabetic nephropathy in Wistar rats. Indian Journal of Experimental Biology 2012; 50: 867-874.

11. HOSSEINI A. \& HOSSEINZADEH H. A review on the effects of Allium sativum (Garlic) in metabolic syndrome. Rocz Panstw Zakl Hig. 2015; 65(1):1-8.

12. Bancroft JD. And Gamble M. (1996): Theory and practice of histological techniques.

13. OJIEH, UGORJI AE., OVUAKPORAYE IS., EWHRE OL. \& OSSAI NR. Comparative Evaluation of Hypoglycemic Properties of Raw and Boiled Allium cepa in Alloxan-Induced Diabetes Mellitus Rats. UK Journal of Pharmaceutical and Biosciences 2015.

14. HERICHOVÁ I., ZEMAN M., STEBELOVÁ K. Expression of per2 and dbp in the heart and liver and melatonin rhythm in the pineal gland of Wistar rat; (2005): 270(1-2):223-229.

15. EBOMOYI, MAUREEN I. \& ABUDA O. Blood glucose and morphology of the liver and pancreas in garlic -fed Wistar rats. Journal of Medicinal Plants Research 2010; 4(18): 1877-1882.

16. KHALAF A. \& GEHAN B. A histological study on the possible protective role of garlic in diabetesinduced structural changes in the renal cortex of adult male albino rats. The Egyptian Journal of Histology 2012; 35 (4): 812-821.

17. MACIEJEWSKI R., BURDAN F., HERMANOWICZ D.T., WOJCIK K. \& WOJTOWICZ Z. Changes in the activity of some lysosomal enzymes in the fine structure of submandibular gland due to experimental diabetes. Acta. Physiol. Hung. 1999; 86(2):127-137.

18. ATISOOK K., CARLSON S., MANDARA JL. Effects of phlorizin and sodium on glucose-elicited alterations of cell junctions in intestinal epithelia. Am J. Physiol. Cell Physiol. 1999; 258:77-85.

19. RAND S., PETROFSKY JS. \& ZIMMERMAN G. Sweat response and heart rate variability during electrical stimulation in controls and people with diabetes. Journal of Applied Research 2008.

20. SILVA JAF., LORENCINI M., REISH JRR., CARVALHO HF., CANGNON VHA. \& STACHMACHADO DR. Influence of type I DM in periodontal diseases induced changes of the gingival epithelium and connective tissue. Tissue and cell 2008;40(4):283-292.

21. CRAIG R.G., ZHAO YU, XU L., BARR R., RAMAMURTHY N., BOLAND J., SCHNEIR M. \& GLOUB L.M. A chemically modified tetracycline inhibits Streptozotocin- induced diabetic depression of skin collagen synthesis and steady-state type I procollagen. Mrna. Biochemica et Biophysica Acta. $1998 ; 1402: 250-260$

22. LIJIMA R., NDREPEPA G., MEHILLI J., MARKWARDT C., BRUSKINA O., PACHE J., IBRAHIM M., SCHÖMIGA. \& KASTRATI A. Impact of diabetes mellitus on long-term outcomes in the drug-eluting stent era. 2007; 154:688-693.

23. LEITE A., HENRIQUE S., SANTOS S., RODRIGUES L., GUILHEN E. ,VESIANI A., FERREIRA M., CRISTINA J., PÔRTO J. \& LEIDA M. Mass Deficiency in FVB/N Mice Produces Marked Changes in Lipid and Glycemic Metabolism 2008; 57(2): 340-347.

24. NELSON A. R., FINGLETON B., Rothenberg M. L. \& MATRISIAN L.M. Matrix Metalloproteinases: Biologic Activity and Clinical Implications. J Clin Oncol. 2000; 18:1135-1149.

25. AKIYA O., Serizawa N., SUGIHARA M., Katagiri S. \& KAWASHIMA Y. A histological study of changes in the lingual papillae of streptozotocininduced diabetic rats. Bull Tokyo Dent Coll. 1992;33(1):13-24.

26. MOHAMMED $\mathrm{H}$. The influence of Ozonized olive oil gel on the dorsal surface of the tongue of Streptozotocin induced diabetic albino rats. Journal of American Science 2013; 9(10):193-201.

27. PAI MH., KO TL. \& CHOU HC. Effects of streptozotocin-induced diabetes on taste buds in rat vallate papillae. ActaHistochem. 2007; 109(3): 200-207.

28. CHOU HC., CHEIN CL., HUANG HL. \& LU KS. Effects of Zink deficiency on the vallate papillae and taste buds in rats. J Formos Med Assoc. 2001; 100:326-335.

29. MORRIS P.A., PROUT R.E.S., PROCTOR G.B., GARRETT \& ANDERSON L.C. Lipid analysis of the major salivary glands in streptozotocin-diabetic rats and the effects of insulin treatment. Archs Oral Biol. 1992;37(6):489-494.

30. MALHOTRA A., PENPENJKU S., FEIN F.S., SONNENBLICK E.H. \& SCHENER J. The effect of streptozotocin induced diabetes in rats on cardiac contractile proteins. Circ. Res. 1981; 49(6): 1243-1250.

31. Robinson-White C. A. and Stratakis. N. Y. (2002): Protein Kin se A a Signaling, "Cross-talk" with other Pathways in Endochrine CElls, Acad. Sci.; 968: 256-270.

32. PATUMRAJ S, TEWIT S, AMATYAKUL $\mathrm{S}$, JARIYAPONGSKUL A, MANEESRI S, KASANTIKUL V, SHEPRO D. Comparative effects of garlic and aspirin on diabetic cardiovascular complications. Drug Deliv. 2000; 7:91-96. 
33. ZHANG X.H., LOWE D., GILES P., FELL S., CONNOCK M.J. \& MASLIN D.J. Gender may affect the action of garlic oil on plasma cholesterol and glucose levels of normal subjects. J Nutr. 2001; 131:1471-1478.

34. JAIN S., PANDHI P., SINGH A.P. \& MALHORTA S. Efficacy of standardized herbal extracts in type 1 diabetes-an experimental study. Afr J Tradit Complement Altern Med.2006; 3:23-33.

35. MAHESAR H., Bhutto M., KHAND A. \& NAREJO N. Garlic used as an alternative medicine to control diabetic mellitus in alloxan-induced male rabbits. Pak J Physiol. 2010; 6:1-11.

36. ALI S., MANAL H., BADAWI A., RANIA
G. \& FOAD M. B. Macroscopic and Microscopic Study of Allium sativum (Garlic) Oil Effects on Post-Operative Intra-Abdominal Adhesion in Diabetic and Non-diabetic Male Rats. Research Article Open Access 2016; 16:26-42.

37. ELDIN I.M.T., AHMED E.M. \& ABD ELWAHAB H.M. Hypo- glycemic activity and regeneration of pancreatic beta-cells produced by Allium cepa in alloxan-induced diabetic rats. Omdurman Journal of Pharmaceutical 2009; 562-568.

38. LEE H., KIM J., KIM H., SHONG M., JEONG B. \& KYEONG E. Upregulated NLRP3 Inflammasome Activation in Patients With Type 2 Diabetes. 2013; 62(1): 194-204. 
الملخص العربى

دراسة مقارنة لتأثير الثوم والبصل والإنسولين على الحليمات اللسانية للفئران البيضاء

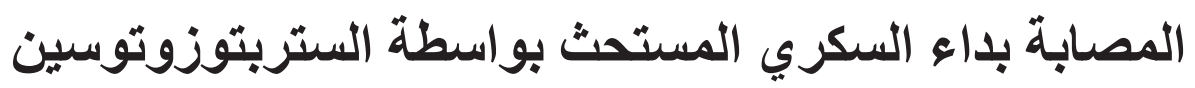

رانية أحمد محمود عواد، ريهام أحمد عبد ربه

قسم بيولوجيا الفم، كلية طب الاسنان، جامعة عين شمس

داء السكري هو مرض أيضي مزمن شائع. يصحب داء السكري عدد مثنوع من الأمر اض الإلتهابية و أمر اض الأنسجة الرخوة. إن مما يدعو إلى القلق من مرض السكري هو الأكسدة وما يترتب عليها من تر اكم الثقائق الحرة في الأنسجة. إن مضادات الأكسدة تمنع حدوث مضاعفات مرض السكري. إن البصل والثوم يعتبرو ا مضادات أكسدة قوية. لذلك فإن هذه الدر اسة أعدت لتحديد مدى قدرة البصل و الثوم على الحد من مضاعفات مرض السكري مقارنة بالإنسولين.

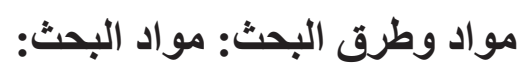
• ستربتوزوتوسين: تم شر اؤه من شركة سيجما في هيئة مسحوق ثم إذابته في محلول الستر ات قبل الإستخدام مباشرة. • مسحوق الثوم. • مسحوق البصل. • (الإنسولين. طرق البحث: تم إستخدام •0 فأر ا في هذه الدراسة، وتم تقسيم الفئران عشوائيا إلى خمس مجموعات تحتوي كل مجمو عة على عشرة فئر ان. أ) المجمو عة الضابطة: وفيها تم حقن الفئر ان بمحلول السيتر ات داخل الصفاق لمرة و احدة في بداية الدر اسة. ب) مجمو عة داء السكري الغير معالجة: وفيها تم حقن • ع فأر ا بالستربتوزوتوسين بجر عة ـ مهج/كجم من وزن الجسم داخل الصفاق مرة واحدة في بداية الدر اسة. بعد مرور يومين، إعتبرت الفئران ذات مستوى السكر في الدم أكثر من • ه مجم/ديسي لتر مصابة بداء السكري. • ( فئران بقيت بدون علاج، في حين أن الثلاثون الأخرين تمت معالجتهم كالآتي: ت) المجمو عة المعالجة بالإنسولين: وفيها تم إعطاء الفئر ان المصابة بالسكري الانسولين عن طريق الحقن تحت الجلد بجر عة ب وحدة للفأر الو احد يوميا لمدة اب يوم.

ث) المجمو عة المعالجة بالثوم: وفيها تم إعطاء الفئر ان المصابة بداء السكري • 0 (مجم/كجم من وزن الجسم من معلق مسحوق الثوم و الماء المقطر مرة واحدة يوميا عن طريق أنبوب الفم وذلك لمدة إب يوم. ج) المجمو عة المعالجة بالبصل: وفيها نم إعطاء الفئر ان المصابة بداء السكري 0 ـ. جم من معلق مسحوق البصل و الماء المقطر لكل فأر مرة واحدة يوميا عن طريق أنبوب الفم وذلك لمدة اب يوم. 
تم التضحية بالفئر ان في نهاية التجربة بإعطائهم جر عة زائدة من المخدر، ثم تم تثريحهم بعد ذلك مباثرة للحصول على الألسنة وتم تجهيز العينات وتحضير ها لفحصها بالطرق الآتية:

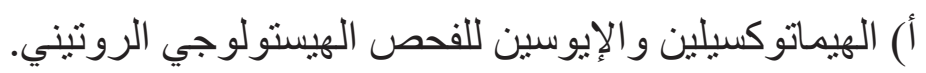
ب) الفحص بالميكروسكوب الإلكتروني الماسح.

نتائج البحث: أسفر فحص الثر ائح المصبو غة بصبغة الهيماتوكسيلين و الإيوسين عن النتائج التالية: • أو لا الحليمات الخيطية: حدوث تغيرات واضحة في المجموعة المصابة بالسكري الغير معالجة حيث تغير الثكل وقصرت بعض الحليمات مع تهنكات في طبقة الكير اتين في مناطق عديدة، ونقص في سمكه في مناطق أخرى مع وجود

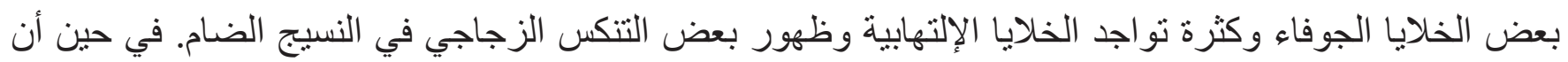
الحليمات الخيطية تحسنت بشكل ملحوظ في باقي المجمو عات المعالجة. • ثانيا الحليمات الفطرية: كان هناك نقص إلى حد ما في حجم الحليمات في المجمو عة الدصابة بالسكري بجانب بعض

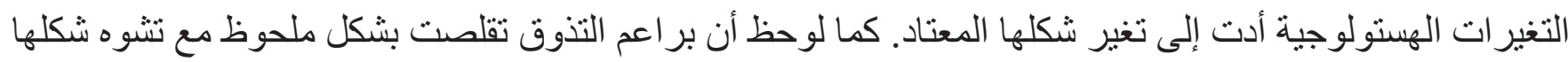
المميز. في حين أن هذه الحليمات تحسنت بشكل ملحوظفي باقي المجمو عات المعالجة خاصة المجموعة المعالجة بالثث م. • ثالثا الحليمات المحيطية: لوحظ في المجمو عه الدصابة بالسكري رقة وبعض التهناك في النسيج الطلائي وانفصال في طبقة الكير اتين، كما اتسع الخندق المحيط بالحليمات ونقص عدد بر اعم التذوق. وقد لوحظ تحسن واضح في هذه الحليمات في المجمو عات المعالجة سو اء بالإنسولين أو الثثوم أو البصل مع ملاحظة تحسن بر اعم التذوق من حيث الثنكل

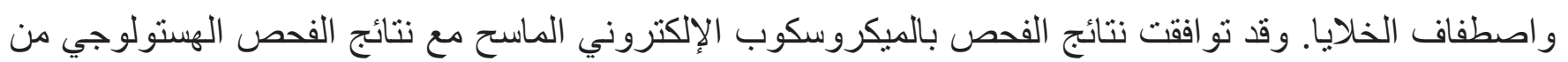
حيث التغير الملحوظ في شكل وترتيب الحليمات اللسانية الخيطية في المجموعة المصابة بالسكري مع تغير إتجاهها، كما لوحظ إنساع الخندق المحيط بالحليمات المحيطية. في حين أنه حدث تحسن ملحوظ في في غالبية الحليمات اللسانية في

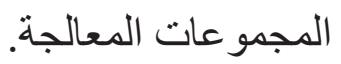

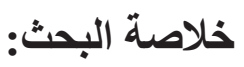
• إصابة الفئران البيضاء البالغة بداء السكري كان له تأثئر سلبي شديد على النسيج الطلائي و الضام وبر اعم التذوق للحليمات اللسانية. • كلا من معلق اثوم والبصل كان له تأثير مساعد واضح في تحسن الحليمات اللسانية وتقليل التأثير الضار لمرض السكري مقارنة بالإنسولين الذي ساهم أيضا في تحسن ملحوظ للحليمات اللسانية. 